\title{
Management of Radon Data in the State of Ohio, U.S.A.
}

\author{
Ashok Kumar*, Charanya Varadarajan, and Akhil Kadiyala*
}

Department of Civil Engineering, The University of Toledo, 2801 W. Bancroft St.,Toledo, Ohio-43606, USA

\begin{abstract}
The objective of this research paper is to create a public awareness in understanding the radon gas problem, discuss efficient data management methods and analyses of indoor radon gas concentrations, and mitigate the indoor radon gas concentrations to below acceptable level in the state of Ohio. The Ohio Radon Information System (ORIS) is a compendium of five databases or modules, viz. the "Homes" database, the "Water" database, the "Schools" database, the "Mitigation" database, and the "Tester" database. Over the years, the radon database (made available by testing laboratories, Ohio Department of Health (ODH), Ohio Environmental Protection Agency (EPA), and universities) has been expanded to 145,849 radon gas observations for homes; 1,283 radon gas observations for drinking water; 1,147 radon gas observations for schools; 26,374 radon gas observations for mitigation systems; and 76,727 radon gas observations by testers. Analysis of the homes data shows that "Licking County" is the only county having a geometric mean $(\mathrm{GM}=8.41 \mathrm{pCi} / \mathrm{l})$ of radon gas concentration greater than $8 \mathrm{pCi} / 1$ in Ohio. Zip code 43930, in "Jefferson County," accounts for a maximum GM radon gas concentration of $39 \mathrm{pCi} / 1$. Of the 216 public and 1,067 private water supply systems, only 2 public and 65 private water supply systems have shown radon gas concentrations to exceed $1000 \mathrm{pCi} / 1$. Analysis of the schools data reveals that a school in "Belmont County" to show a maximum radon gas concentration of $85.5 \mathrm{pCi} / \mathrm{l}$, with 11 rooms out of the 39 school rooms tested greater than $4 \mathrm{pCi} / \mathrm{l}$. The performance analysis of the mitigation systems identified the Sub Slab Depressurization (SSD) systems to be the best performers in mitigating the radon gas concentration to below $4 \mathrm{pCi} / \mathrm{l}$ in Ohio. Analysis of the tester's data showed two counties: Harrison $(\mathrm{GM}=$ $10.25 \mathrm{pCi} / \mathrm{l})$; and Perry $(\mathrm{GM}=8.65 \mathrm{pCi} / \mathrm{l})$ to have a $\mathrm{GM}$ of radon gas concentration greater than $8 \mathrm{pCi} / 1$ in Ohio.
\end{abstract}

Keywords: Radon, database, environmental management system, Ohio, indoor air pollution, Ohio Radon Information System (ORIS), mitigation systems, data analysis, Radon gas environmental monitoring.

\section{INTRODUCTION}

Radon gas is a naturally occurring, colorless, odorless, radioactive gas. It is a by-product of the breakdown of uranium and radium. Radon gas is continuously released from rocks and soil containing these two elements. Radon gas drifts upward through the ground to the surface of the soil and seeps into the buildings through foundation cracks. Radon gas is formed naturally by radioactive decay of uranium present in geologic materials. The major sources of radon gas in Ohio are 'Ohio shale' and soil. Organic shale in Ohio is known to have elevated concentrations (10 ppm to $40 \mathrm{ppm}$ ) of uranium, five to 20 times the average levels in the earth's crust $[1,2]$. When uranium decays, it forms radon gas that enters homes through soil, underground water, and water distribution systems and in a gaseous form through cracks and other openings [3].

Elevated radon gas levels have been discovered in virtually every state. The United States Environmental Protection Agency (U.S. EPA) estimates that as many as eight million homes throughout the country have elevated levels of radon gas [4]. Since 1988, EPA and the Office of the Surgeon General have recommended that homes below

*Address correspondence to these authors at the Department of Civil Engineering, The University of Toledo, 2801 W. Bancroft St.,Toledo, Ohio-43606, USA; Tel: 419-530-8120; Fax: 419-530-8116;

E-mail: akadiya@rockets.utoledo.edu, akumar@utnet.utoledo.edu the third floor be tested for radon gas. EPA's action level for public safety is an indoor radon gas concentration of $4 \mathrm{pCi} / 1$, where immediate measures should be taken to reduce the level to $2 \mathrm{pCi} / 1$ [5].

Radon gas is a national environmental health problem. It is a well-known human carcinogen, recognized as the second leading cause of lung cancer [4]. When inhaled, high indoor concentrations of radon gas can damage the lung tissue and increase the risk of cancer. An individual's risk of developing lung cancer from radon gas increases with the level of radon, the duration of exposure, and the individual's smoking habits [6]. As people spend most of their time at home, home is the most significant source of radon gas exposure. For school children, the school buildings are the second largest source of radon gas exposure, the first source being their homes.

Children are more sensitive to radon gas because they have smaller lungs and higher respiratory rates. According to the available estimates, 21,000 people die from lung cancer each year in the United States, due to exposure to indoor radon gas [4]. On an average, 900 deaths in Ohio alone are caused by lung cancer. This is because the average indoor radon gas concentration in the state is well above the national average of $1.3 \mathrm{pCi} / 1$ [1].

When high radon gas levels were discovered in eastern Pennsylvania in the early 1980s, the U.S. EPA initiated a radon gas mitigation campaign. In late 1980, the Ohio Department of Health $(\mathrm{ODH})$ initiated an indoor radon gas pro- 


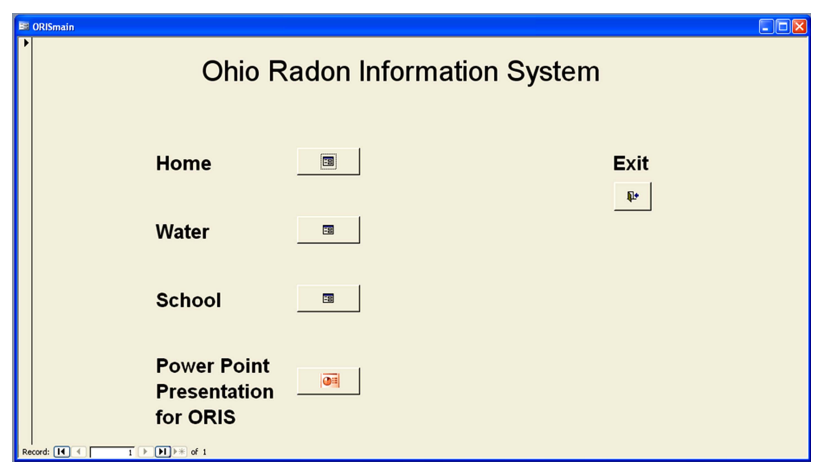

Fig. (1). Main form of the integrated radon gas database.

gram to reduce the number of deaths attributable to radon gas. During the 1990s, ODH started encouraging the reduction of radon gas concentrations in houses and schools to a safe level through a number of mitigation methods. In 2001, Ohio passed a law that required radon gas mitigation contractors to report mitigation data on homes to ODH [7]. As a result of the new law, two new databases were developed to study radon gas mitigation systems and to track observations by testers.

The University of Toledo, under several research grants from the $\mathrm{ODH}$ and the Ohio Air Quality Development Authority, developed the Ohio Radon Information Systems (ORIS), and a website [1, 2, 5, 8, 9]. The purpose of this database is to help the public understand the hazards of radon gas and, therefore, reduce any of its concentration levels that surpass the U.S. EPA's action limits.

This paper discusses the development of the five different databases and the respective results from the analysis of radon gas data for different counties and zip codes in Ohio. The analyses and results contribute significantly towards understanding the radon gas problem in Ohio.

\section{RADON GAS DATABASES}

The Ohio Radon Information System (ORIS) is one of the most comprehensive indoor radon gas databases available in the world. The extensive radon gas database maintained by the Department of Civil Engineering, The University of Toledo, is an integrated database of three sections: viz. "Homes", "Water", and "Schools", and separate databases on "Mitigation" and "Tester". A number of queries built into the SQL server and MS Access are run to analyze the data to get valuable results.

The "Homes" database provides information on the radon gas concentration measured using radon detectors in homes in Ohio. The "Homes" section, the most extensive of all the sections of the databases, began as an ORACLE/MS Access database [10]. It is currently handled by SQL Server 7.0/MS Access, as MS Access on its own is incapable of handling such a large database [11]. The data table is stored in SQL Server 7.0, and the interlinking between the MS Access and the Server is furnished with the help of linked tables and pass through queries. The "Water" and "School" databases are smaller in size and, therefore, handled by MS Access. This integrated database is a user-friendly environment wherein the entire system can be accessed through MS Ac-
Table 1. Number of Records on Radon Gas Concentration in Homes Database and Supplier Information

\begin{tabular}{|c|c|c|}
\hline Organization & Number of Records & Year \\
\hline The University of Toledo & 50626 & Before 1989 \\
\hline Airchek, Inc. & 59568 & 1990-2009 \\
\hline Maintenance Management. & 75 & 1990-1998 \\
\hline Delaware Health Department & 1175 & 1990-1998 \\
\hline Radonics, Inc. & 4079 & 1990-2009 \\
\hline $\begin{array}{l}\text { RSSI/Radiation Safety } \\
\text { Services, Inc. }\end{array}$ & 1350 & 1990-1998 \\
\hline Radon Testing Corp., Inc. & 6487 & 1990-2009 \\
\hline Solar Testing Laboratories & 3289 & 1990-1998 \\
\hline Key Technology, Inc. & 713 & 1990-2009 \\
\hline Radalink, Inc. & 5197 & 1990-2009 \\
\hline Landauer, Inc. & 8422 & 1990-2009 \\
\hline Niton Corporation & 733 & 1990-1998 \\
\hline Radon Systems & 259 & 1999 \\
\hline Licking County Department & 671 & 1999 \\
\hline Globe Spec & 1065 & 1999-2009 \\
\hline Lake County & 92 & 1999 \\
\hline Warren & 102 & 1999-2009 \\
\hline Valle Inc. & 49 & 1999 \\
\hline Bass Home Inspection & 722 & 1999-2009 \\
\hline Miscellaneous & 1175 & \\
\hline Total & 145849 & \\
\hline
\end{tabular}

cess forms (screens). A single form called ORIS main allows access to the entire database (refer Fig. 1). New data can be added using these MS Access front ends. Resultantly, complete knowledge of MS Access and SQL Server, when the duties of database maintenance change hands, can be eliminated. Microsoft Excel 2007 is also being used to handle such a large database. Currently, the "Homes" database is the largest database with 145,849 data points, as of December 2009. It can be observed from literature that limited studies have given a detailed description of the structure of the database $[8,12]$ and only one study provided a comprehensive analysis of radon gas concentration and house construction parameters [13].

Data for homes are provided by various organizations and radon gas testing laboratories as electronic files. Table $\mathbf{1}$ shows the sources of the data received and their contributions.

The raw data provided by these labs are then preprocessed for inclusion in the "Homes" database. The "Homes" database consists of one main table and a number of associated queries, as given below for the analysis of the data. 


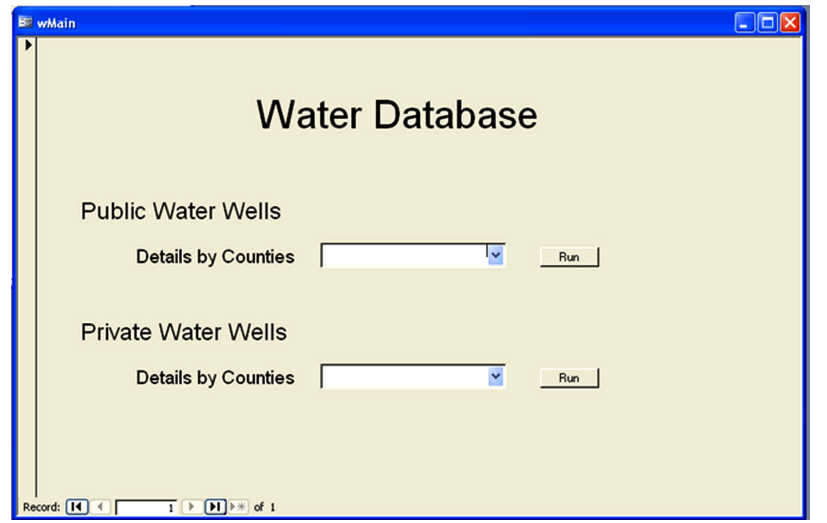

Fig. (2a). Water database access form.
4) Counties with GM of radon gas concentration > 4 pCi/l: This query lists all the counties with GM of radon gas concentration greater than $4 \mathrm{pCi} / 1$.

5) Counties with GM of radon gas concentration $>8$ pCi/l: This query lists all the counties with GM of radon gas concentration greater than $8 \mathrm{pCi} / 1$.

6) Zip codes with GM of radon gas concentration > 4 pCi/l: This query lists all the zip codes with GM of radon gas concentration greater than $4 \mathrm{pCi} / \mathrm{l}$.

The "Water" database has observations on radon concentrations in water across the state of Ohio and consists of two sets of controls viz. public water wells and private water

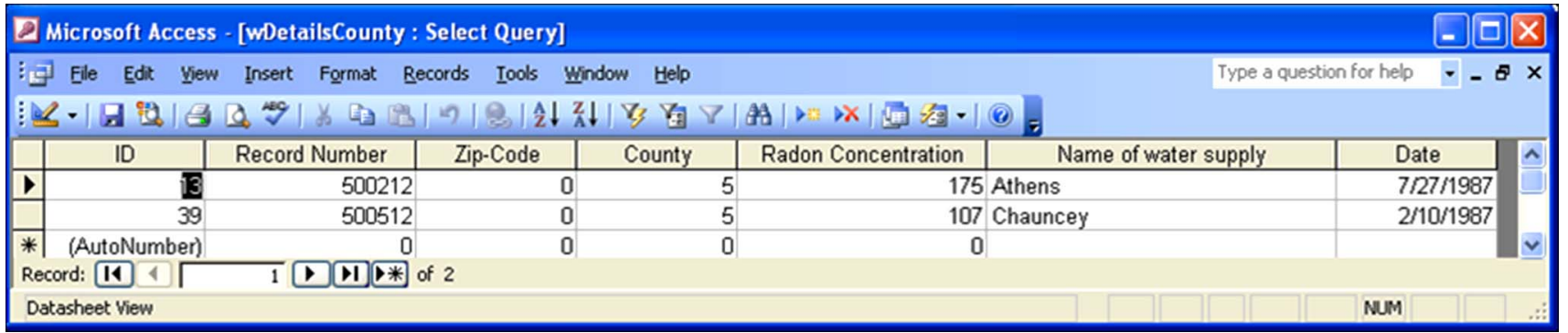

Fig. (2b). Public water supply county query.

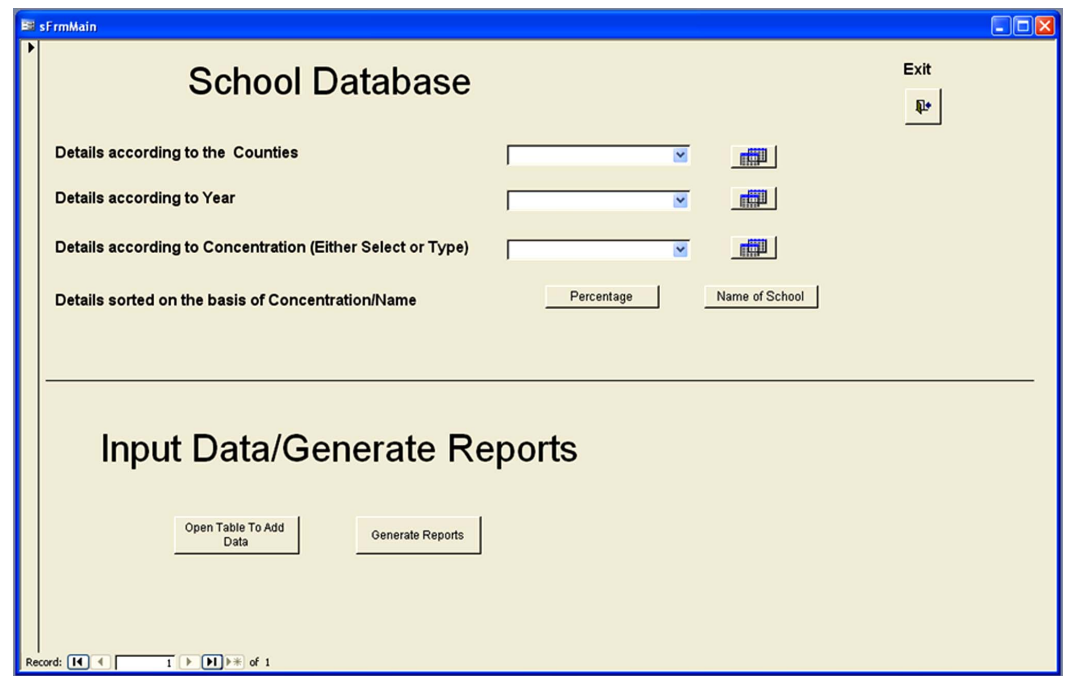

Fig. (3). School database main form.

1) Radon gas statistics based on counties: This query calculates the statistical parameters such as total number of radon gas measurements for a particular county, the maximum radon gas concentration in a particular county, the minimum radon gas concentration in a particular county, the arithmetic mean (AM) of radon gas concentrations, the geometric mean (GM) of radon gas concentrations, first quartile, third quartile, median, the standard deviation, and the variance all grouped according to the counties.

2) Overall statistics for the entire state of Ohio: This query displays the above-mentioned statistics for the entire state of Ohio.

3) Radon gas statistics based on zip codes: This query is similar to that of the county statistics and displays all statistics based on zip codes. wells. The information on public water wells was supplied by the Ohio EPA, and private water wells were obtained from the Master of Science theses completed at Ohio Universities. The list of MS theses used were listed on the radon website maintained by the air pollution research group (APRG) of the Department of Civil Engineering at The University of Toledo [14]. The associated county queries for each of these controls display information for all the public and private wells in that particular county (Fig. 2a and Fig. 2b). Currently, the "Water" database consists of 1,283 data points from 72 counties as of December 2009. Of these 1,283 water supply systems, 216 are public water wells and 1,067 are private wells.

The "Schools" database is a collection of radon gas information measured in public and private schools in Ohio. The main form of the school database (Fig. 3) has three sets 
Table 2. Detailed School Information

\begin{tabular}{|c|c|c|}
\hline Serial Number & Grades Span & School Name \\
\hline \hline IRN Number & District Name & School Street Address \\
\hline County Number & District Street Address & School City \\
\hline District Type & District City & School Zip Code \\
\hline Miscellaneous Data & District Zip Code & School Telephone \\
\hline District Number & District Telephone & Title \\
\hline School Type & District County & Staff Name \\
\hline
\end{tabular}

of controls that are used for accessing and segregating the school data according to the county, year, and radon gas concentration. The 'Percentage' and 'Name of School' command buttons display the radon gas data based on the radon gas concentration and school name respectively.

The data on details of school and the measurements of radon gas concentrations in different schools of Ohio are provided by the ODH. Currently, the "Schools" database has 1,147 radon gas measurement data as of December 2009. The database consists of two main tables, besides forms for each table and related queries. The main table comprises of the data sent by ODH at regular intervals. The fields in the school database include 1) Name of School, 2) County, 3) Number of rooms tested for radon, 4) Number of rooms where the radon gas concentration exceeded the permissible level of $4 \mathrm{pCi} / \mathrm{l}, 5)$ Maximum radon gas concentration level observed in that school, and 6) Year in which the measurements were made. The second table records the complete information on the schools, where these radon gas measurements were conducted. This table houses fields as given in Table 2.

Table 2 was born out of the exhaustive data provided by the Ohio Board of Regents on the public and private schools in Ohio, and gives the complete information on schools. Forms created for each of these tables, using the Form Wizard provided by MS Access, help as a front-end application to manipulate the data in the tables and to add new data. It also helps users avoid the complexity posed by the table structure. A number of queries built in MS Access help in the analysis of the school data. The results of the queries provide an insight into the levels of radon gas concentrations in the schools of Ohio. Queries along with a description are given below.

1) Number of schools tested by county and year: This query gives the list of the number of schools tested in each county on a yearly basis. The list is grouped based on the year.

2) Number of schools tested by year: This query gives the number of schools in Ohio that are tested each year. It contains data from 1990 to 2009 .

3) Schools with radon gas concentrations $\geq 4 \mathrm{pCi} / \mathrm{l}$ : This query identifies all the schools in Ohio that have a maximum radon gas concentration greater than or equal to 4 $\mathrm{pCi} / \mathrm{l}$. This table lists the name of the school, county, maxi- mum radon gas concentration, and the year in which it was tested.

4) Schools with radon gas concentrations $\geq 8 \mathrm{pCi} / \mathrm{l}$ : This query gives the list of all the schools in the state of Ohio that have a maximum radon gas concentration greater than or equal to $8 \mathrm{pCi} / \mathrm{l}$. It also contains the same fields, as mentioned above.

5) Schools with radon gas concentrations $\geq 20 \mathrm{pCi} / \mathrm{l}$ : This query lists all the schools in the state of Ohio that have a maximum radon gas concentration greater than or equal to $20 \mathrm{pCi} / 1$.

6) Schools by percentage of rooms tested having radon gas concentration $\geq \mathbf{4} \mathbf{~ p C i} /$ : This query shows the percentage of rooms in every school which have a radon gas concentration greater than or equal to $4 \mathrm{pCi} / \mathrm{l}$.

7) Schools with more than 15 rooms having radon gas concentration $\geq 4 \mathrm{pCi} / \mathrm{l}$ : This query is designed to retrieve the names of all the schools from the database which have more than 15 rooms in which the concentration of radon gas is greater than or equal to $4 \mathrm{pCi} / 1$.

8) School statistics: This query gives the total number of schools tested in each county, the maximum and minimum school radon gas concentration in the counties, the AM and GM of radon gas concentration in the counties, the standard deviation and the variance for the counties. A total of 63 counties have been tested as of December 2009.

The "Mitigation" database is a collection of radon gas mitigation systems installed in Ohio homes. The "Mitigation" database is prepared in MS Access to store, update, retrieve, and analyze the mitigation data [15]. Licensed contractors perform the mitigation tests and submit the results to the ODH. This data is manually entered into an Excel sheet in one main table. The data are checked for accuracy and transcription errors. The stored data is updated every quarter of the year and the reports of the analysis are submitted to the ODH for each quarter. Currently, the "Mitigation" database has 26,374 data points, as of December 2008. The database includes information pertinent to 1) license number of the contractor; 2) name of the contact; 3) telephone number; 4) street address of the contact; 5) zip code, city, county, and state; 6) type of mitigation system; 8) start and finish dates of the mitigation test;9) pre-mitigation and post mitigation levels; 10) quarter of the year; and 11) year.

Data are analyzed by transferring the Excel sheet to MS Access. The data consists of both complete and incomplete information. Complete information implies records have both the pre-mitigation and post-mitigation levels. Missing values are assigned codes for convenience. "NA" represents missing values of an alpha-numeric type, while " 1 " indicates missing numeric parameters. For ease of data entry and use of the mitigation systems and their combinations, the quarter of the year are also assigned distinct codes.

Analysis of the data is performed by using a number of queries (listed below) built in MS access for this purpose.

1) Number of records by each license number of the contractor: This query gives the total number of tests performed by each contractor. 
2) Counties with pre-mitigation level $>4 \mathrm{pCi} / \mathrm{l}$ : This query identifies the counties which have the pre-mitigation level more than $4 \mathrm{pCi} / \mathrm{l}$.

3) Average removal efficiency by each type of system: This query gives the average percent removal achieved and the standard deviation for each type of system.

4) Pre-mitigation level between $4 \mathrm{pCi} / \mathrm{l}$ and $20 \mathrm{pCi} / \mathrm{l}$ : This query identifies the records that have the pre-mitigation level between $4 \mathrm{pCi} / \mathrm{l}$ and $20 \mathrm{pCi} / \mathrm{l}$.

5) Pre-mitigation level $>20 \mathrm{pCi} / \mathrm{l}$ : This query identifies the records that have the pre-mitigation level greater than 20 pCi/l.

Only complete data are considered for the analysis. Queries have been designed in a manner that they account for all kinds of missing data. Operations such as counting the number of records in a particular category and grouping the data based on specific criteria are performed by the queries. The results of the queries provide an insight into the effectiveness of the mitigation program conducted across Ohio.

The "Tester" database is a collection of the radon test systems installed in Ohio homes. The "Tester" database maintenance procedure is similar to that of the maintenance procedure adopted for the "Mitigation" database. The tester database is also prepared in MS Access to store, update, retrieve, and analyze the tester data. The APRG in the Civil Engineering Department at The University of Toledo receives radon gas tester results from licensed testers through $\mathrm{ODH}$. This data is manually entered into an Excel sheet in one main table, and the data are checked for accuracy and to avoid transcription errors. The stored data is updated every quarter of the year and the reports of the analysis are submitted to the ODH for each quarter. Currently, the tester database has 76,727 data points as of December 2008. The database includes information on 1) license number of the tester; 2) name of the contact; 3 ) street address of the contact; 4) zip code, city, county, and state; 5) device code; 6) test type; 7) start and finish dates of the test; 8) radon gas concentration level; 9) quarter of the year; and 10) and year in which the measurements were made.

Data are analyzed by transferring the Excel sheet to MS access. The data consists of both complete and incomplete information. Incomplete information relates to any missing radon gas concentration values. Missing values are assigned codes of "-1" or "NA" for numeric and alpha-numeric parameters respectively. Analysis of the data is carried out by using a number of queries (listed below) built in MS access for this purpose.

1) Number of records by each license number of the tester: This query gives the total number of tests completed by each tester.

2) Counties with radon gas concentration level $>4$ pCi/l: This query identifies the counties which have the radon gas concentration level more than $4 \mathrm{pCi} / \mathrm{l}$.

3) Radon gas statistics for each county: This query computes statistics such as total number of radon gas measurements, maximum and minimum radon gas concentrations, $\mathrm{AM}, \mathrm{GM}$, standard deviation, and variance, all grouped according to the counties.
4) Radon gas statistics for each zip code: This query is similar to that of the county statistics and displays all statistics based on zip codes.

Only complete data are considered for the analysis. Queries have been designed in a manner that they account for all kinds of missing data. "Tester" database management is similar to "Mitigation" database management, and the query results provide further insight into the radon gas testing program in Ohio.

\section{RESULTS AND DISCUSSION}

The analysis of radon gas data in each of the database provides an insight into the distribution of radon gas concentration across Ohio, and reveals zip codes, counties, and schools that have a real-time radon gas issue. The results further help the concerned authorities take necessary steps toward mitigating radon gas and evaluating the effectiveness of the various programs undertaken to reduce the radon gas levels to below the EPA action limit. Common statistical parameters are calculated and quoted separately.

The home database includes measurements from all the 88 counties in Ohio. The analysis of homes data revealed 25 counties having $\mathrm{GM}$ of radon gas concentration greater than $4 \mathrm{pCi} / \mathrm{l}$, while Licking County $(\mathrm{GM}=8.41 \mathrm{pCi} / \mathrm{l})$ is the only county with the GM of radon gas concentration greater than $8 \mathrm{pCi} / \mathrm{l}$. Of the available 1,491 zip code areas in the homes database, $32.19 \%$ have GM radon gas concentrations over 4 $\mathrm{pCi} / \mathrm{l}$, and $1.98 \%$ have concentrations over $8 \mathrm{pCi} / \mathrm{l}$. The zip code 43930 in Jefferson County accounts for a maximum $\mathrm{GM}$ radon gas concentration of $39 \mathrm{pCi} / \mathrm{l}$. The $\mathrm{GM}$ of radon gas concentration is $3.67 \mathrm{pCi} / 1$ for Ohio, based on the 145,849 records. Figs. (4 and 5) display the spatial distribution of GM of the radon gas concentration in Ohio for different counties and zip codes respectively. From Fig. (4), one can observe Jefferson County to have its GM radon gas concentration value between $2 \mathrm{pCi} / \mathrm{l}$ and $4 \mathrm{pCi} / \mathrm{l}$, despite the location of zip code 43930 with the highest GM radon gas concentration value of $39 \mathrm{pCi} / \mathrm{l}$ within the same county. This can be explained on studying the influence of uranium concentrations on radon gas concentrations in Ohio. The uranium concentration map for Ohio is available on the ORIS website [16]. Zip code 43930 had relatively higher uranium concentration as compared to the uranium concentrations monitored in other zip codes of Jefferson County. Also, the availability of only three data points for zip code 43930 could have resulted in the highest GM for radon gas concentrations for the same zip code. A more detailed analysis of the uranium and radon gas concentrations across the state of Ohio showed that majority of the zip codes having radon gas GM concentration greater than $4 \mathrm{pCi} / \mathrm{l}$ to be having have higher uranium concentrations. From these observations, one can conclude that uranium concentrations and radon gas concentrations in Ohio correlated well.

Of the 1,283 water supply systems, 216 are public water wells and 1,067 are private wells. Of the 216 public water wells, only two showed radon concentration greater than $1000 \mathrm{pCi} / \mathrm{l}$. However, none of the public water supply systems have concentrations greater than $1500 \mathrm{pCi} / \mathrm{l}$. Table 3 shows the statistics for radon concentration in the private water wells in Ohio counties. From Table 3, one can observe 


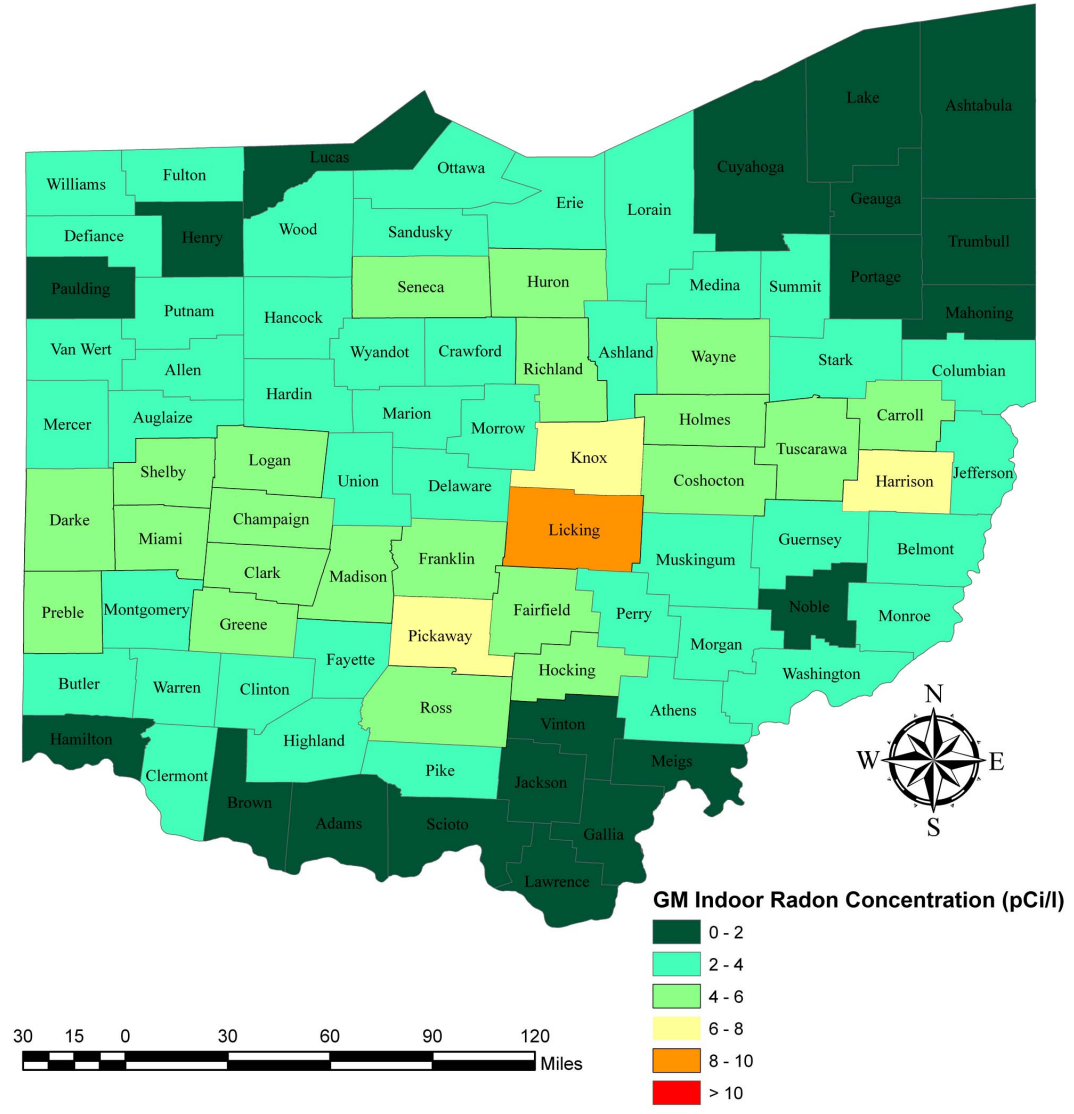

Fig. (4). Geometric mean indoor radon gas concentration in Ohio counties.

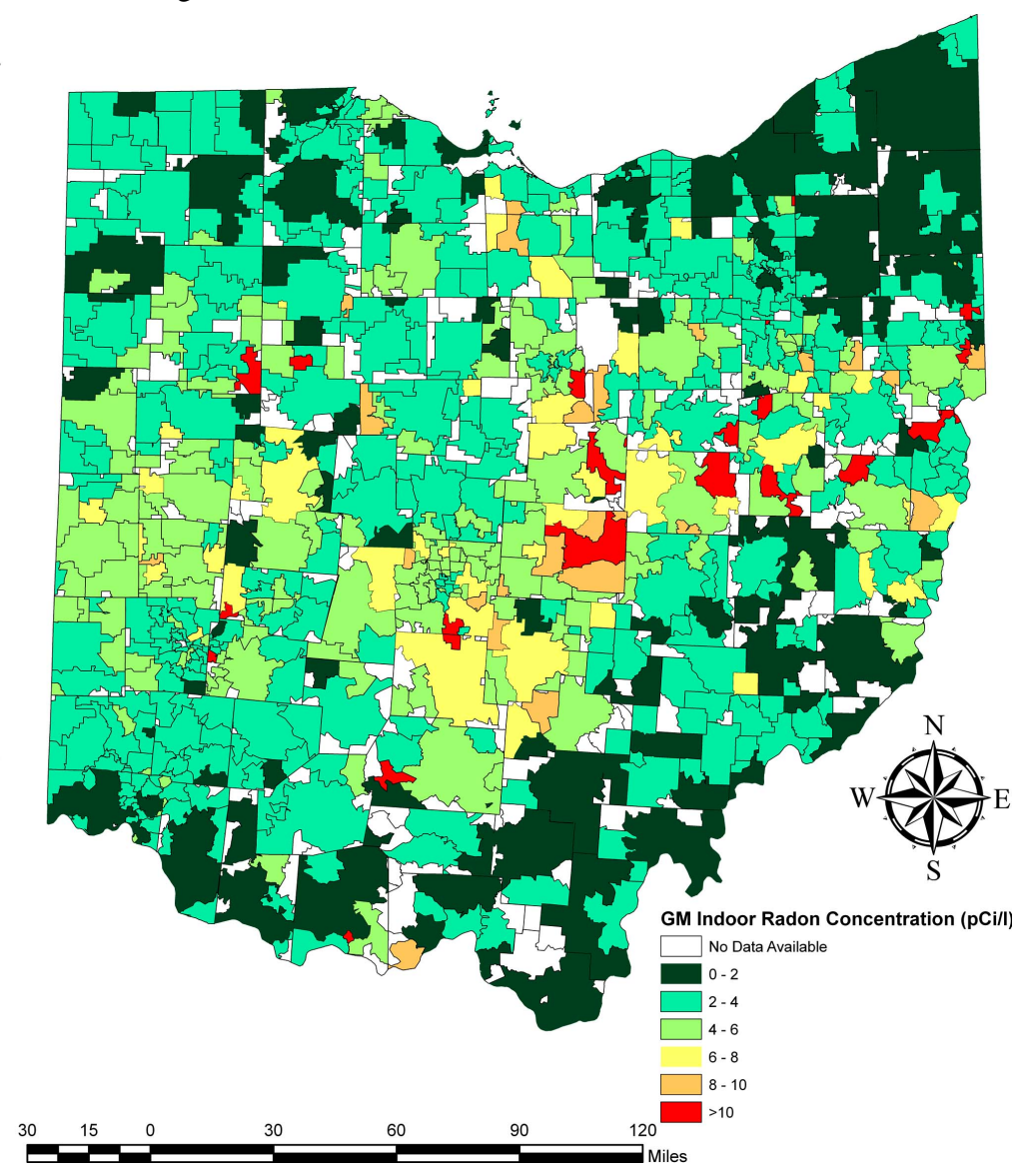

Fig. (5). Geometric mean indoor radon gas concentrations in Ohio zip codes. 
Table 3. Radon Concentration in Private Water Wells in Counties of Ohio

\begin{tabular}{|c|c|c|c|c|c|}
\hline Counties & $\begin{array}{l}\text { Total Number } \\
\text { of Wells }\end{array}$ & $\begin{array}{l}\text { Maximum Radon } \\
\text { Concentration }(\mathrm{pCi} / \mathrm{l})\end{array}$ & $\begin{array}{c}\text { Minimum Radon } \\
\text { Concentration (pCi/l) }\end{array}$ & $\begin{array}{c}\text { Average Radon } \\
\text { Concentration } \\
\text { (pCi/l) }\end{array}$ & $\begin{array}{c}\text { Number of Wells with Radon } \\
\text { Concentration } \geq 1000 \mathrm{pCi} / \mathrm{l}\end{array}$ \\
\hline Butler & 7 & 571 & 217 & 415.00 & 0 \\
\hline Champaign & 80 & 1491 & 73 & 355.85 & 2 \\
\hline Clark & 8 & 1386 & 172 & 436.88 & 1 \\
\hline Darke & 1 & 231 & 231 & 231.00 & 0 \\
\hline Delaware & 60 & 2314 & 2 & 599.12 & 13 \\
\hline Erie & 181 & 3104 & 20 & 285.82 & 6 \\
\hline Fulton & 3 & 172 & 119 & 147.00 & 0 \\
\hline Hancock & 7 & 470 & 180 & 322.86 & 0 \\
\hline Hardin & 49 & 996 & 44 & 238.73 & 0 \\
\hline Henry & 1 & 510 & 510 & 510.00 & 0 \\
\hline Huron & 149 & 2010 & 5 & 230.82 & 7 \\
\hline Logan & 212 & 7511 & 25 & 553.99 & 28 \\
\hline Marion & 74 & 1574 & 26 & 257.61 & 3 \\
\hline Miami & 4 & 413 & 174 & 248.00 & 0 \\
\hline Montgomery & 6 & 637 & 249 & 406.67 & 0 \\
\hline Union & 5 & 334 & 82 & 210.40 & 0 \\
\hline Warren & 4 & 542 & 340 & 442.00 & 0 \\
\hline Williams & 8 & 245 & 148 & 185.25 & 0 \\
\hline Wood & 6 & 560 & 200 & 320.00 & 0 \\
\hline Wyandot & 6 & 180 & 96 & 132.00 & 0 \\
\hline
\end{tabular}

65 private wells to have radon concentrations exceeding $1000 \mathrm{pCi} / \mathrm{l}$. Of these 65 wells, 28 were located in Logan County, while 13 were found in Delaware County. It is interesting to note that from the available data on private wells, seven private wells have radon gas concentration greater than $3000 \mathrm{pCi} / 1$.

The ODH School Testing Program has covered 63 counties and 1,147 schools (Figs. 6 and 7). The number of schools having maximum radon gas concentration $>=4 \mathrm{pCi} / 1$ and $8 \mathrm{pCi} / 1$ in at least one room are 259 and 133 respectively. Analysis of the schools data reveals that a school in "Belmont County" showed a maximum radon gas concentra- tion of $85.5 \mathrm{pCi} / 1$, with 11 rooms out of the 39 school rooms tested greater than $4 \mathrm{pCi} / 1$.

Table 4 presents the number of schools having maximum radon gas concentration $>=20 \mathrm{pCi} / 1$ in at least one room is 20. Fig. (8) shows the school counties with percentage of rooms greater than $4 \mathrm{pCi} / \mathrm{l}$. The map reveals that Pike county schools have approximately $50-60 \%$ of rooms greater than 4 pCi/l. In Ohio, based on current data available at The University of Toledo for 1,147 schools, it is estimated that approximately $27.6 \%$ of schools have a potential for at least one room in excess of the EPA action level ( $4 \mathrm{pCi} / \mathrm{l})$ compared to $19.3 \%$ nationwide. 


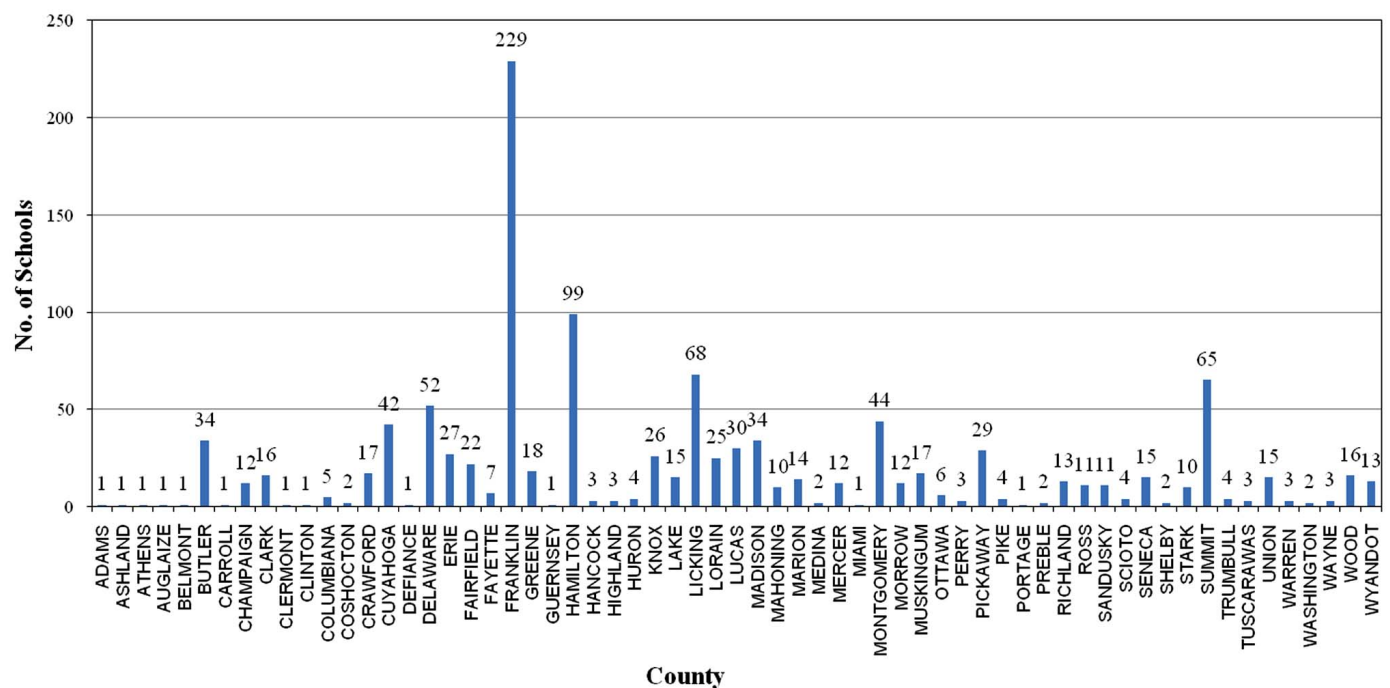

Fig. (6). Number of schools tested per county.

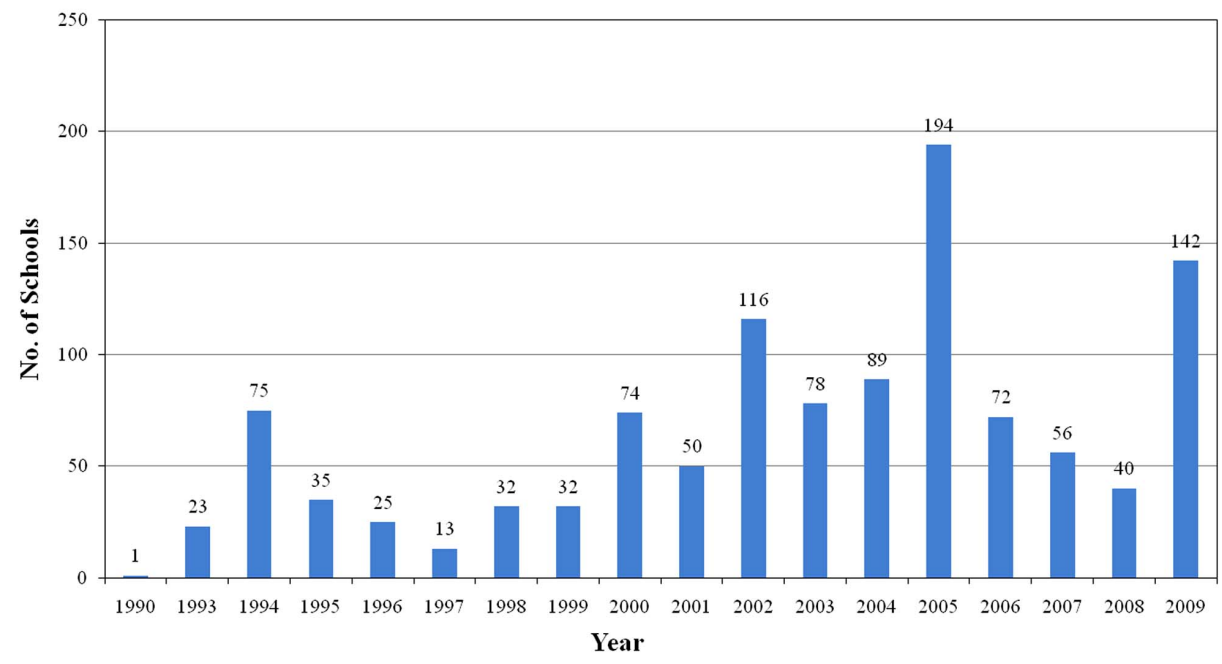

Fig. (7). Number of schools tested per year.

Table 4. Schools Having Radon Concentrations $>=20 \mathrm{pCi} / \mathrm{l}$

\begin{tabular}{|c|c|c|c|c|}
\hline School Name & County & Rooms Tested & $\begin{array}{c}\text { Maximum } \\
\text { Radon Gas Concentration } \\
>=\mathbf{2 0 P C I} / \mathrm{L}\end{array}$ & Year \\
\hline OLNEY FRIENDS SCHOOL & BELMONT & 39 & 85.5 & 2009 \\
\hline SOUTH MAIN ELEMENTARY & WOOD & 11 & 70.3 & 1996 \\
\hline EAST PRIMARY ELEMENTARY SCHOOL & PIKE & 33 & 53 & 2000 \\
\hline NORTH ELEMENTARY & COLUMBIANA & 20 & 48 & 2005 \\
\hline WEST MUSKINGUM HIGH SCHOOL & MUSKINGUM & 39 & 44.9 & 2001 \\
\hline WORTHINGWAY MIDDLE SCHOOL & FRANKLIN & 41 & 39.8 & 1998 \\
\hline LIT BASES@HUBBARD & FRANKLIN & 19 & 34.5 & 2007 \\
\hline BECK URBAN ACADEMY & FRANKLIN & 17 & 33.8 & 2007 \\
\hline DUNLOE ELEMENTARY & FRANKLIN & 32 & 32.3 & 2006 \\
\hline TOBOSO ELEMENTARY & LICKING & 15 & 29.3 & 2004 \\
\hline COLUMBIA ELEMENTARY & KNOX & 3 & 29 & 2004 \\
\hline
\end{tabular}




\begin{tabular}{|c|c|c|c|c|}
\hline NORTH RIDGE LOCAL SCHOOL DISTRICT & LICKING & 123 & 24.6 & 2009 \\
\hline FAIRFIELD MIDDLE SCHOOL & BUTLER & 135 & 24 & 2003 \\
\hline OAK GROVE ELEMENTARY & WASHINGTON & 12 & 22 & 2002 \\
\hline ASBURY ELEMENTARY & FRANKLIN & 29 & 21.8 & 2006 \\
\hline PRECIOUS BLOOD CATHOLIC SCHOOL & MONTGOMERY & 19 & 21.7 & 2008 \\
\hline GRANIVILLE CHRISTIAN ACADEMY & LICKING & 41 & 20.7 & 2003 \\
\hline
\end{tabular}

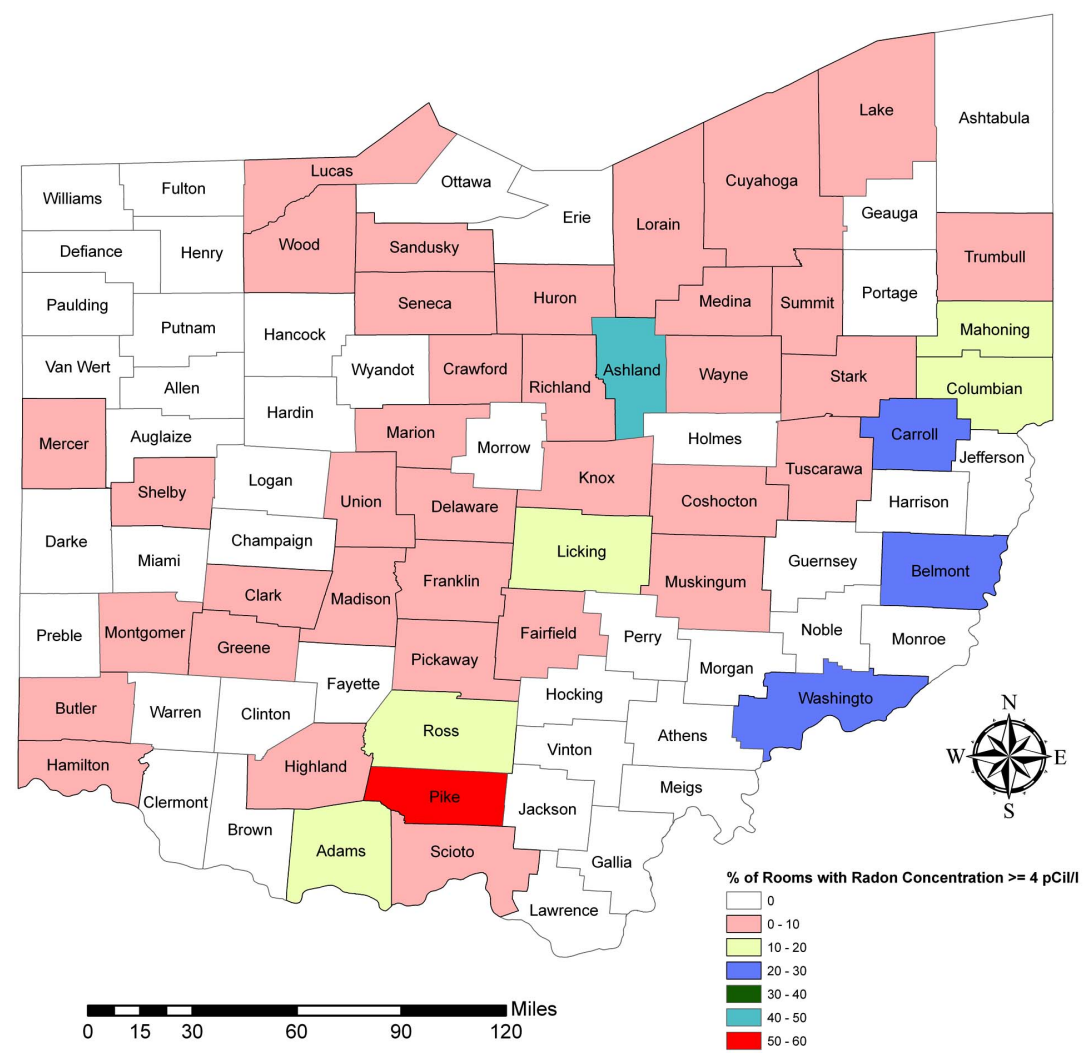

Fig. (8). Counties with percentage of school rooms with radon gas concentration $>=4 \mathrm{pCi} / \mathrm{l}$.

"Mitigation" database query results provide an insight into the effectiveness of the mitigation program conducted in the state. The results of the data analysis pertain to the collection period of January 2001 to December 2008.

The total number of records and the number of complete records by quarter are shown in Table 5. Out of 26,374 records reported, 20,321 records (about $77.61 \%$ ) were found complete (i.e., having pre-mitigation and post-mitigation levels). It can be observed from Table 5 that the percentage of complete records is increasing over the years. The efforts by ODH were productive because the percent of complete records increased from $2.32 \%$ to $97.18 \%$, for the period from 2001 to 2008. The yearly average of complete records (per- centage) has increased from $20.38 \%$ in 2001 to $95.09 \%$ in 2008. The number of records with pre-mitigation level between $4 \mathrm{pCi} / 1$ and $20 \mathrm{pCi} / 1$ for each year is shown in Table 6. The number of records with percentage removal less than 50 percent for each year is shown in Table 7. One can easily say that the mitigation installation in Ohio has been successful, because only a small percent of the installations with complete records have removal efficiency less than 50\%. Table 8 presents the performance analysis of different mitigation systems used in Ohio for the year 2008. Statistical testing (based on the standard error of mean values that accounts for both the number of records per mitigation system and the respective standard deviation) of the percentage removal by 
Table 5. Total Number of Mitigation Records

\begin{tabular}{|c|c|c|c|c|c|}
\hline Quarter & $\begin{array}{l}\text { Total Number of } \\
\text { Records }\end{array}$ & $\begin{array}{l}\text { Number of Complete } \\
\text { Records }\end{array}$ & $\begin{array}{c}\text { Total Records } \\
\text { Submitted Yearly }\end{array}$ & $\begin{array}{l}\text { Complete Records } \\
\text { Submitted Yearly }\end{array}$ & $\begin{array}{c}\text { Percentage } \\
\text { Complete } \\
\text { Records }\end{array}$ \\
\hline Quarter 1 (Jan.-Mar. 2001) & 647 & 15 & & & 2.32 \\
\hline Quarter 2 (Apr.-Jun. 2001) & 940 & 169 & & & 17.98 \\
\hline Quarter 3 (Jul.-Sep. 2001) & 953 & 208 & & & 21.83 \\
\hline Quarter 4 (Oct.-Dec. 2001) & 978 & 325 & 3518 & 717 & 33.23 \\
\hline Quarter 1 (Jan.-Mar. 2002) & 722 & 228 & & & 31.58 \\
\hline Quarter 2 (Apr.-Jun. 2002) & 829 & 320 & & & 38.60 \\
\hline Quarter 3 (Jul.-Sep. 2002) & 1041 & 512 & & & 49.18 \\
\hline Quarter 4 (Oct.-Dec. 2002) & 716 & 472 & 3308 & 1532 & 65.92 \\
\hline Quarter 1 (Jan.-Mar. 2003) & 651 & 530 & & & 81.41 \\
\hline Quarter 2 (Apr.-Jun. 2003) & 1010 & 908 & & & 89.90 \\
\hline Quarter 3 (Jul.-Sep. 2003) & 1018 & 807 & & & 79.27 \\
\hline Quarter 4 (Oct.-Dec. 2003) & 825 & 619 & 3504 & 2864 & 75.03 \\
\hline Quarter 1 (Jan.-Mar. 2004) & 454 & 411 & & & 90.53 \\
\hline Quarter 2 (Apr.-Jun. 2004) & 705 & 686 & & & 97.30 \\
\hline Quarter 3 (Jul.-Sep. 2004) & 36 & 36 & & & 100.00 \\
\hline Quarter 4 (Oct.-Dec. 2004) & 877 & 846 & 2072 & 1979 & 96.47 \\
\hline Quarter 1 (Jan.-Mar. 2005) & 680 & 650 & & & 95.59 \\
\hline Quarter 2 (Apr.-Jun. 2005) & 229 & 220 & & & 96.07 \\
\hline Quarter 3 (Jul.-Sep. 2005) & 1124 & 1076 & & & 95.73 \\
\hline Quarter 4 (Oct.-Dec. 2005) & 838 & 795 & 2871 & 2741 & 94.87 \\
\hline Quarter 1 (Jan.-Mar. 2006) & 898 & 864 & & & 96.21 \\
\hline Quarter 2 (Apr.-Jun. 2006) & 844 & 796 & & & 94.31 \\
\hline Quarter 3 (Jul.-Sep. 2006) & 825 & 776 & & & 94.06 \\
\hline Quarter 4 (Oct.-Dec. 2006) & 835 & 797 & 3402 & 3233 & 95.45 \\
\hline Quarter 1 (Jan.-Mar. 2007) & 579 & 509 & & & 87.91 \\
\hline Quarter 2 (Apr.-Jun. 2007) & 802 & 783 & & & 97.63 \\
\hline Quarter 3 (Jul.-Sep. 2007) & 999 & 931 & & & 93.19 \\
\hline Quarter 4 (Oct.-Dec. 2007) & 714 & 653 & 3094 & 2876 & 91.46 \\
\hline Quarter 1 (Jan.-Mar. 2008) & 849 & 800 & & & 94.23 \\
\hline Quarter 2 (Apr.-Jun. 2008) & 1100 & 1059 & & & 96.27 \\
\hline Quarter 3 (Jul.-Sep. 2008) & 1530 & 1437 & & & 93.92 \\
\hline \multirow[t]{2}{*}{ Quarter 4 (Oct.-Dec. 2008) } & 1126 & 1083 & 4605 & 4379 & 96.18 \\
\hline & 26374 & 20321 & & & 77.61 \\
\hline
\end{tabular}


Table 6. Number of Records with Pre-Mitigation Level Between 4 pCi/l and 20 pCi/l for the Years 2001 to 2008 (Jan.-Dec.)

\begin{tabular}{|c|c|}
\hline Year & Number of Records with Pre-ML Between 4 pCi/l \& 20 pCi/l \\
\hline \hline 2001 & 631 \\
\hline 2002 & 1325 \\
\hline 2003 & 2597 \\
\hline 2004 & 1773 \\
\hline 2005 & 2450 \\
\hline 2006 & 1463 \\
\hline 2007 & 2971 \\
\hline 2008 & 3905 \\
\hline
\end{tabular}

Table 7. Number of Records with \% Removal Less than 50 for years 2001 to 2008

\begin{tabular}{|c|c|c|}
\hline Year & Number of Records with Removal \% Less Than 50 & Percentage of Records with Removal \% Less Than \\
$\mathbf{5 0}$ & $0.70 \%$ \\
\hline \hline 2001 & 25 & $2.00 \%$ \\
\hline 2002 & 67 & $2.40 \%$ \\
\hline 2003 & 70 & $3.49 \%$ \\
\hline 2004 & 69 & $6.07 \%$ \\
\hline 2005 & 174 & $4.08 \%$ \\
\hline 2006 & 67 & $2.40 \%$ \\
\hline 2007 & 69 & $1.70 \%$ \\
\hline
\end{tabular}

Table 8. Average Removal Efficiency by Each Type of System for year 2008

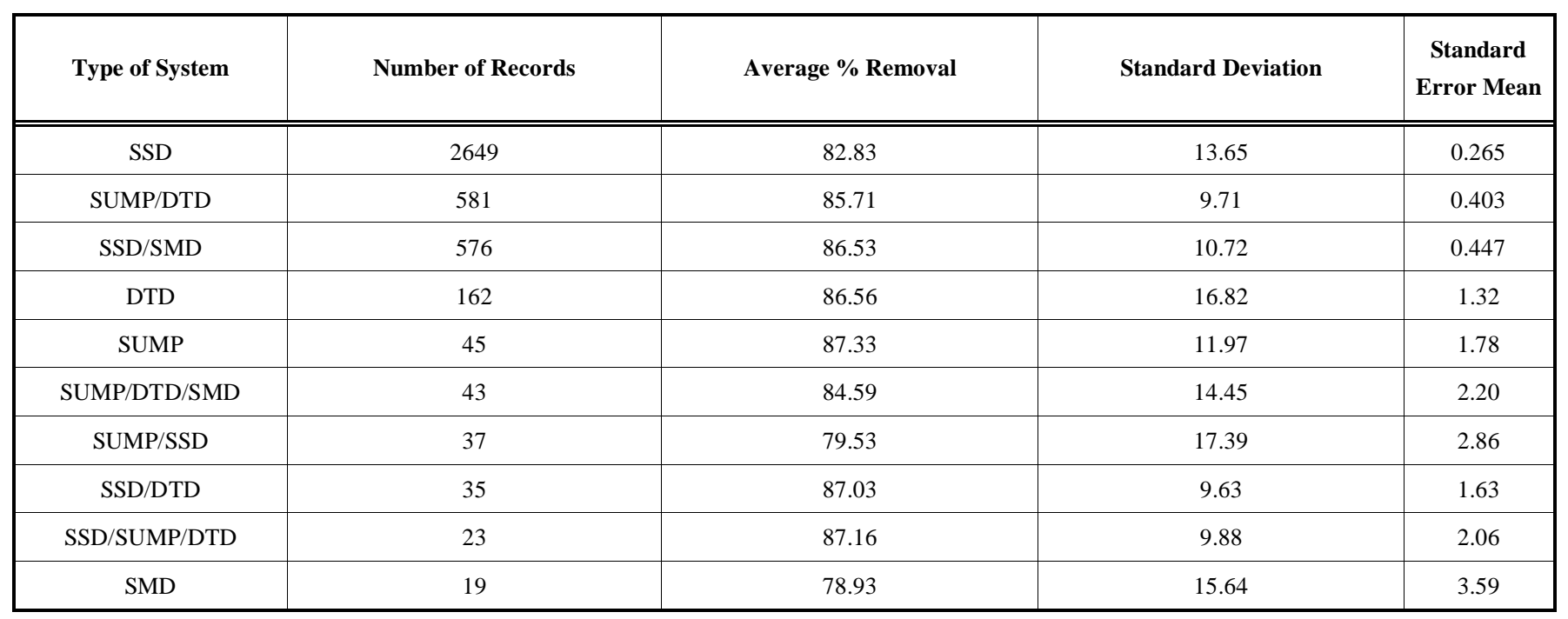

different mitigation systems revealed the Sub Slab Depressurization (SSD) system to be the best in mitigating the radon gas concentrations to below $4 \mathrm{pCi} / 1$ for all the years (refer to Table 8 for 2008 summary of percentage removal for different mitigation systems). Figs. (9) and (10) show the plots of variation of the removal efficiency with the pre-mitigation and post-mitigation levels for the best system. From Fig. (9), one can observe the efficiency of the mitigation systems to decrease with decrease in pre-mitigation level. This is because radon gas concentrations cannot be reduced below a certain level. From Fig. (10), it can be noted that average efficiency of the mitigation system decreases with an increase in the post-mitigation level. 


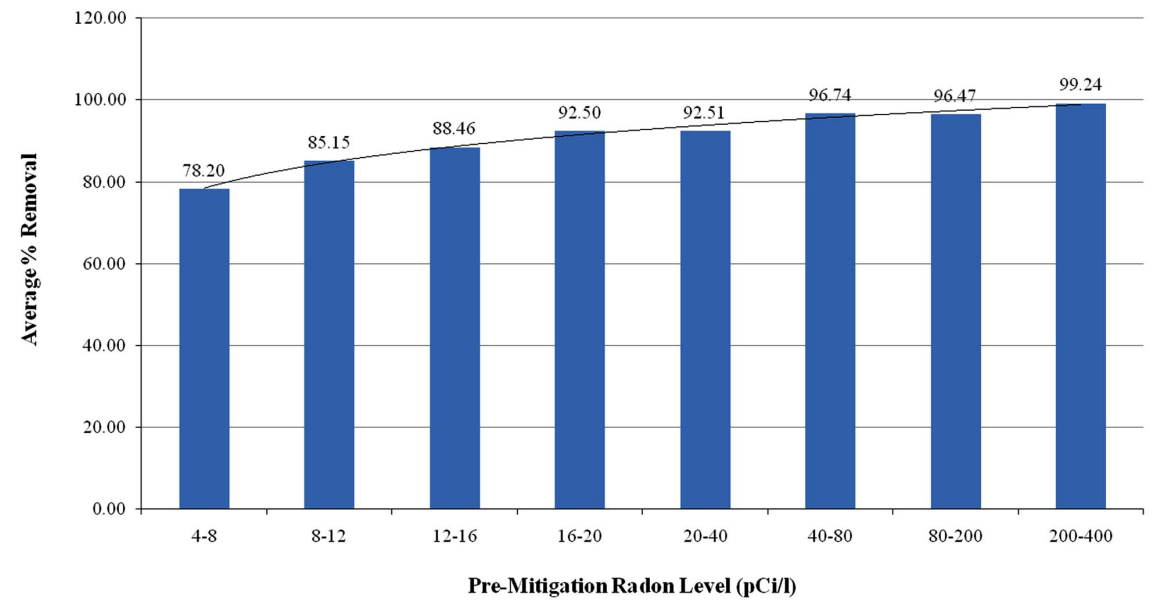

Fig. (9). Variation of removal efficiency with pre-mitigation level for the best performing system (SSD) for year 2008.

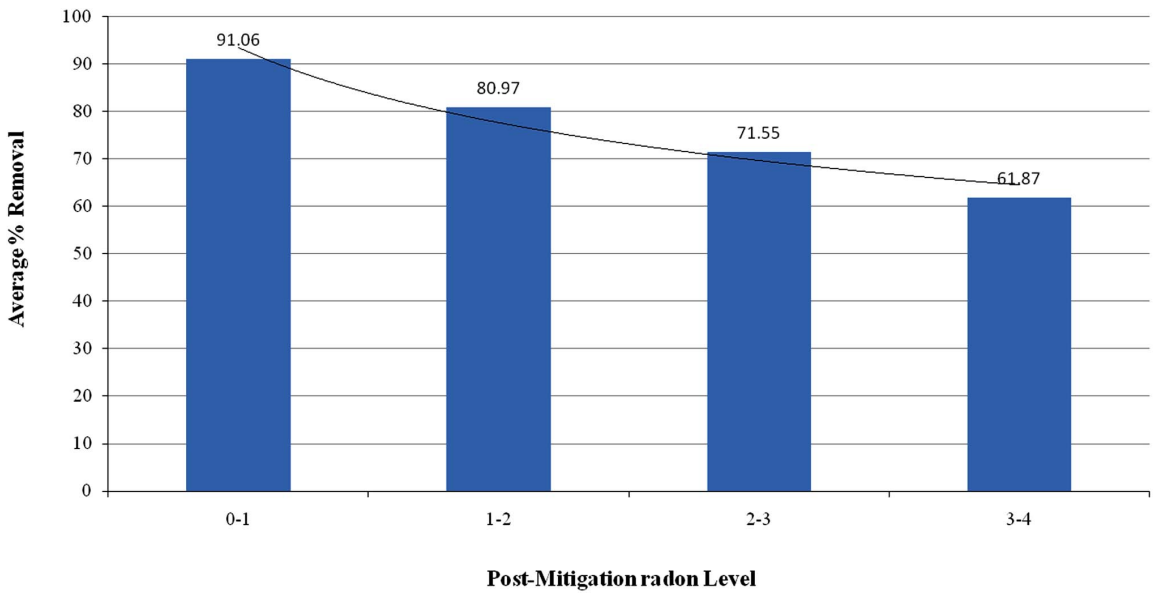

Fig. (10). Variation of removal efficiency with post-mitigation level for the best performing system (SSD) for year 2008.

"Tester" database query results provide more insight into the radon gas concentration levels observed in different counties and zip codes across Ohio. The results of the tester data analysis pertain to the collection period of January 2002 to December 2008. The total number of records and the number of complete records by quarter are shown in Table $\mathbf{9}$. Out of 76,727 records reported, 76,280 records (about 99.41 $\%$ ) were found complete (i.e., having radon gas test levels). It can be observed from Table 9 that there are very few incomplete records in the tester database since 2001. Table $\mathbf{1 0}$ provides the statistics for counties with tester radon gas GM $>=4 \mathrm{pCi} / \mathrm{l}$. There are 28 counties that have radon gas test levels above $4 \mathrm{pCi} / \mathrm{l}$ (refer Table 10). Harrison $(\mathrm{GM}=10.25$ $\mathrm{pCi} / \mathrm{l})$ and Perry $(\mathrm{GM}=8.65 \mathrm{pCi} / \mathrm{l})$ are the two counties to have $\mathrm{GM}$ of radon gas test levels greater than $8 \mathrm{pCi} / 1$ in Ohio.

\section{ORIS ON THE WEB}

The Ohio Radon Information System, an internet site on radon gas in Ohio is open to public, and was specifically developed to assist the State of Ohio in managing its indoor radon gas problem [17]. The main purpose of this site is to create awareness of the radon gas problem among Ohio's citizens, and provide information on methods of radon gas reduction, to minimize the threat to their health. Besides assisting homeowners, the site also serves various professional constituencies, including radon gas testers, building contractors, realtors, physicians, and government health officials. The information on the ORIS website mainly focuses on the radon gas in Ohio. The ORIS site is divided into the following nine sections: Information on Radon, Preventative Measures, Testing Procedures, Health Risks, Radon Concentrations across Ohio, Lists of Radon Professionals, Other Sources of Information, Geology of Radon, and F.A.Q. (Frequently Asked Questions) [5].

The ORIS website hosts the results from the analyses in the form of tables and Geographic Information System (GIS) [9] maps for the public along with information about radon gas, its health hazards, geologic controls and remediation strategies, and the geographic distribution of radon gas using an indoor radon gas database from 88 counties and more than 1400 zip codes in Ohio. The website hosts the publicly available results of all the radon gas tests in Ohio. The website covers a host of radon gas related issues and addresses some of the major public concerns. This website also has in-depth information from various reliable sources that, calculate important statistical parameters, use advanced computing techniques that are user friendly. It is a graphically superior and interactive website. To enhance the usability and information storehouse of the site, a complete database of the radon gas measurements, over the entire period, is incorporated. The main strength of the site is the 
Table 9. Total Number of Tester Records

\begin{tabular}{|c|c|c|c|c|c|}
\hline Quarter & Number of Records & $\begin{array}{c}\text { Number of Complete } \\
\text { Records }\end{array}$ & $\begin{array}{c}\text { Records Submitted } \\
\text { Yearly }\end{array}$ & $\begin{array}{l}\text { Complete Records } \\
\text { Submitted Yearly }\end{array}$ & $\begin{array}{c}\text { Percentage of Complete } \\
\text { Records }(\%)\end{array}$ \\
\hline Quarter 1 (Jan.-Mar. 2002) & 449 & 446 & & & 99.33 \\
\hline Quarter 3 (Jul.-Sep. 2002) & 3503 & 3408 & & & 97.29 \\
\hline \multirow[t]{2}{*}{ Quarter 4 (Oct.-Dec. 2002) } & 2346 & 2286 & & & 97.44 \\
\hline & & & 7020 & 6850 & \\
\hline Quarter 2 (Apr.-Jun. 2003) & 1186 & 1181 & & & 99.58 \\
\hline Quarter 3 (Jul.-Sep. 2003) & 3629 & 3618 & & & 99.70 \\
\hline \multirow[t]{2}{*}{ Quarter 4 (Oct.-Dec. 2003) } & 1137 & 1136 & & & 99.91 \\
\hline & & & 9533 & 9427 & \\
\hline Quarter 1 (Jan.-Mar. 2004) & 1369 & 1364 & & & 99.63 \\
\hline Quarter 4 (Oct.-Dec. 2004) & & & 4851 & 4838 & \\
\hline Quarter 1 (Jan.-Mar. 2005) & 3559 & 3557 & & & 99.94 \\
\hline Quarter 2 (Apr.-Jun. 2005) & 2509 & 2507 & & & 99.92 \\
\hline Quarter 3 (Jul.-Sep. 2005) & 3447 & 3444 & & & 99.91 \\
\hline \multirow[t]{2}{*}{ Quarter 4 (Oct.-Dec. 2005) } & 2592 & 2587 & & & 99.81 \\
\hline & & & 12107 & 12095 & \\
\hline Quarter 1 (Jan.-Mar. 2006) & 2038 & 2033 & & & 99.75 \\
\hline Quarter 2 (Apr.-Jun. 2006) & 6460 & 6439 & & & 99.67 \\
\hline Quarter 3 (Jul.-Sep. 2006) & 2855 & 2851 & & & 99.86 \\
\hline Quarter 4 (Oct.-Dec. 2007) & & & 13695 & 13659 & \\
\hline Quarter 1 (Jan.-Mar. 2008) & 3681 & 3675 & & & 99.84 \\
\hline Quarter 2 (Apr.-Jun. 2008) & 5140 & 5124 & & & 99.69 \\
\hline Quarter 3 (Jul.-Sep. 2008) & 3663 & 3629 & & & 99.07 \\
\hline \multirow[t]{3}{*}{ Quarter 4 (Oct.-Dec. 2008) } & 2789 & 2778 & & & 99.61 \\
\hline & & & 15273 & 15206 & \\
\hline & & & 76727 & 76280 & 99.42 \\
\hline
\end{tabular}

Table 10. Statistics for Counties with Tester Radon Gas Concentration $>=4 \mathrm{pCi} / \mathrm{l}$

\begin{tabular}{|c|c|c|c|c|c|c|c|}
\hline County & Number of Records & Maximum (pCi/l) & Minimum (pCi/l) & $\mathbf{A M}$ & GM & $\begin{array}{l}\text { Standard } \\
\text { Deviation }\end{array}$ & Variance \\
\hline HARRISON & 12 & 50.50 & 0.80 & 10.74 & 10.25 & 6.61 & 83.93 \\
\hline PERRY & 9 & 36.60 & 1.70 & 10.70 & 8.65 & 12.22 & 62.29 \\
\hline ROSS & 16 & 44.60 & 0.50 & 8.15 & 7.91 & 2.65 & 70.83 \\
\hline LOGAN & 30 & 46.10 & 0.40 & 9.13 & 7.56 & 7.49 & 86.55 \\
\hline MASON & 2 & 10.10 & 5.20 & 7.65 & 7.25 & 3.46 & 45.29 \\
\hline
\end{tabular}


Table 10. Cont...

\begin{tabular}{|c|c|c|c|c|c|c|c|}
\hline VAN WERT & 4 & 16.70 & 0.80 & 6.82 & 6.77 & 1.20 & 40.75 \\
\hline ERIE & 131 & 273.20 & 0.05 & 13.34 & 6.76 & 16.28 & 104.27 \\
\hline CARROLL & 34 & 62.10 & 0.40 & 7.87 & 5.69 & 8.78 & 84.24 \\
\hline MADISON & 37 & 36.60 & 0.50 & 7.46 & 5.59 & 7.44 & 94.59 \\
\hline PICKAWAY & 35 & 22.60 & 0.40 & 6.31 & 5.48 & 3.95 & 69.38 \\
\hline DARKE & 17 & 30.10 & 0.60 & 7.07 & 5.32 & 7.44 & 101.99 \\
\hline MARION & 72 & 53.60 & 0.20 & 8.30 & 5.32 & 7.83 & 89.95 \\
\hline AUGLAIZE & 13 & 13.10 & 0.50 & 5.52 & 5.08 & 2.48 & 54.11 \\
\hline COSHOCTON & 8 & 7.80 & 0.70 & 5.30 & 5.08 & 2.40 & 77.56 \\
\hline PIKE & 164 & 16.50 & 0.50 & 5.79 & 4.99 & 3.10 & 53.51 \\
\hline LICKING & 585 & 296.60 & 0.20 & 9.75 & 4.98 & 13.80 & 135.96 \\
\hline KNOX & 138 & 258.00 & 0.40 & 14.60 & 4.95 & 26.13 & 158.11 \\
\hline COLUMBIANA & 116 & 77.10 & 0.20 & 8.83 & 4.93 & 10.09 & 105.32 \\
\hline CHAMPAIGN & 24 & 36.80 & 1.00 & 5.72 & 4.90 & 6.07 & 59.69 \\
\hline HIGHLAND & 6 & 8.80 & 2.30 & 4.88 & 4.88 & & \\
\hline FAIRFIELD & 254 & 54.00 & 0.20 & 7.58 & 4.86 & 7.41 & 97.47 \\
\hline PREBLE & 21 & 21.70 & 0.10 & 5.37 & 4.61 & 4.47 & 69.15 \\
\hline GUERNSEY & 4 & 6.70 & 1.30 & 4.50 & 4.50 & & \\
\hline MORROW & 29 & 22.50 & 0.30 & 5.24 & 4.25 & 3.76 & 69.50 \\
\hline STARK & 1920 & 111.00 & 0.10 & 6.84 & 4.21 & 9.03 & 128.76 \\
\hline TUSCARAWAS & 516 & 134.00 & 0.05 & 7.28 & 4.02 & 10.01 & 127.25 \\
\hline DELAWARE & 1777 & 735.00 & 0.10 & 6.62 & 3.99 & 9.96 & 132.88 \\
\hline FRANKLIN & 7821 & 939.00 & 0.05 & 6.88 & 3.98 & 10.07 & 144.01 \\
\hline
\end{tabular}

availability to users. It has a large, interactive database on Ohio's indoor radon gas levels and geology. Information from these databases is available for every county and most zip code areas within the state.

\section{CONCLUSION}

An integrated radon gas information system has been successfully compiled from the data provided by government agencies, university researchers, and commercial testing companies. The information available from the database is useful in assessing the extent of the radon gas problems in Ohio's homes, public water systems, and schools. It was also possible to determine the best mitigation system to control radon gas problem in Ohio homes and identify the counties and zip codes with radon gas test levels greater than $4 \mathrm{pCi} / \mathrm{l}$. The radon gas website developed during the project helps in creating awareness among Ohio's citizens on radon gas issue and provides information on radon gas reduction and mitigation deaths.

\section{ACKNOWLEDGEMENTS}

The authors are thankful for the research grants (\# 7 to \# 20) awarded by the Ohio Department of Health (ODH) and the United States Environmental Protection Agency (US EPA) to The University of Toledo, which made the development of such a radon gas management system possible. The contributions of earlier investigators of the grants (Dr. Jim Harrell and Dr. Andrew G. Heydinger, and many graduate students who worked on this project over the years) are all greatly acknowledged. The authors also acknowledge the contribution of a number of staff members from the ODH. The views expressed in this paper are those of authors.

\section{REFERENCES}

[1] Harrell JA, McKenna JP, Kumar A. Geological controls on indoor radon in Ohio. Division of Geological Survey Report of Investigations \#144, Ohio Division of Natural Resources 1993; p. 36.

[2] Harrell JA, Belsito ME, Kumar A. Radon hazards associated with outcrops of Ohio shale in Ohio. Environ Geol Water Sci 1991; 18: 17-26.

[3] The American Lung Association, The Environmental Protection Agency, The Consumer Product Safety Commission, The American Medical Association. Indoor air pollution: An introduction for health professionals. Indoor Air Division \#EPA 402-R-94-007, U.S. Environmental Protection Agency 1994; p. 33.

[4] U.S. Environmental Protection Agency. A citizen's guide to radon: The guide to protecting yourself and your family from radon. Indoor Environments Division \#EPA 402-K-02-006, U.S. Environmental Protection Agency 2004, p. 16.

[5] Kumar A, Harrell JA, Heydinger A. Ohio goes online to combat indoor radon. Environ Manager (EM by A\&WMA) 2001; 2: 10-12.

[6] Environment, Health, and Safety Online. Studies of childhood exposure to indoor air pollution; [Cited 2011 Jan 25]. Available from: http://www.ehso.com/ehshome/children3indoorair.htm\#rn

[7] The Ohio Department of Health. Radon licensing program rules and regulations: Ohio Administrative Code 3701-69. Bureau of Radiation Protection, Ohio Department of Health, 2001. Available from: http://www.odh.ohio.gov/odhPrograms/rp/radlic/radlicg/radonrules.aspx

[8] Kumar A, Heydinger A, Harrell, JA. Development of an indoor radon information system for Ohio and its application in the study of geology of radon in Ohio. University of Toledo, Ohio Air Quality Development Authority 1990; p. 201. 
[9] Ojha S, Thomas SJ, Kumar A. Experience in integrating geographical information systems (GIS) to an indoor radon database. Environ Prog 2001; 20: O7-O10.

[10] Kumar A, Sud A, Heydinger A. Application of ORACLE 7.3 database management system for the development of an environmental database. Environ Prog 1998; 17: F11-F14.

[11] Joshi A, Manne GK, Kumar A. Management of Ohio's radon data with MS Access/SQL Server 7.0. Environ Prog 2002; 21: D8-D12.

[12] Heydinger A, Kumar A, Harrell JA. An indoor radon information system. Environ Softw 1991; 6: 194-201.

[13] Harrell JA, Kumar A. Multivariate stepwise regression analysis of indoor radon data from Ohio. J Off Stat 1989; 5: 409-20.
[14] Other Sources of Information. University Theses on Radon in Ohio [Cited July 25 2010]. Available from http://www.eng.utoledo.edu/aprg/radon/wwwsite.html

[15] Kumar A, Tandale A, Kalapati RS, Ghose S. Management of radon mitigation data in the state of Ohio. Environ Prog 2003; 22: O5$\mathrm{O} 10$.

[16] Radon Concentration Statistics for the State of Ohio. Aerial Radiometric Map of Ohio Showing the Concentrations of Uranium in Surfacial Sediments and Soils [Cited July 25 2010]. Available from: http://www.eng.utoledo.edu/aprg/radon/testingapplet $1 . h t m l$

[17] Ohio Radon Information System. [Cited July 6 2010]. Available from http://radon.utoledo.edu

(c) Kumar et al.: Licensee Bentham Open.

This is an open access article licensed under the terms of the Creative Commons Attribution Non-Commercial License (http://creativecommons.org/licenses/ by-nc/3.0/) which permits unrestricted, non-commercial use, distribution and reproduction in any medium, provided the work is properly cited. 